\title{
Tracheal Intubation in Out-Of-Hospital Setting is Associated With A High Failure Rate of The First Attempt: A Multicenter Prospective Study
}

\section{Michel Galinski ( $\square$ michel.galinski@chu-bordeaux.fr)}

Hôpital Pellegrin - CHU de Bordeaux https://orcid.org/0000-0001-9304-339X

\section{Marion Wrobel}

Hôpital François Mitterrand: Centre Hospitalier de Pau, Pôle Urgences - SAMU 64, Hôpital François

Mitterrand: Centre Hospitalier de Pau

\section{Romain Boyer}

CHU de Bordeaux, Hôpital Pellegrin, Urgences adultes - SAMU, CHU de Bordeaux: Centre Hospitalier Universitaire de Bordeaux

\section{Paul Georges Reuter}

Hôpital Raymond-Poincare: Hopital Raymond-Poincare, SAMU 92, Universite Paris-Saclay, UVSQ, Université Paris Sud, INSERM, Equipe Soins Primaires et Prévention, Villejuif 94807

\section{Mirko Ruscev}

Centre Hospitalier de Gonesse, SMUR, 95503, Hospital Centre Gonesse: Centre Hospitalier de Gonesse

\section{Guillaume Debaty}

Hopital de la Tronche: Centre Hospitalier Universitaire Grenoble Alpes, SAMU 38, Universite Grenoble Alpes

\section{Bagou Gilles}

Hospices Civils de Lyon, SAMU 69, GH Edouart Herriot: Groupement Hospitalier Edouard Herriot

\section{Emilie Dehours}

CHU de Toulouse, Hôpital Purpan, SAMU 31, Université de Toulouse

\section{Juliane Bosc}

Hôpital Robert Boulin, Urgences-SMUR, Libourne 33243, CH de Libourne

\section{Jean-Paul Lorendeau}

Centre Hospitalier de Périgueux, SAMU 24, CH de Périgueux

\section{Sybille Goddet}

Centre Hospitalier Universitaire de Bordeaux, SAMU 21, CHU de Dijon

\section{Kamelia Marouf}

CHU d'Angers, SAMU 49, Centre Hospitalo-Universitaire d'Angers

\section{Pierre Catoire}

Centre Hospitalier Universitaire de Bordeaux, Urgences adultes - SAMU 33, INSERM U1219 Team IETO: Bordeaux Population Health Research Centre Team IETO 
Cédric Gil-Jardiné

Centre Hospitalo Universitaire de Bordeaux, Urgences Adultes - SAMU 33, INSERM U1219 Team IETO:

Bordeaux Population Health Research Centre Team IETO

\section{Bruno Simonnet}

Centre Hospitalo Universitaire de Bordeaux, Urgences Adultes - SAMU 33, Hopital Pellegrin

\section{Original research}

Keywords: First intubation attempt, difficult intubation, Prehospital emergency setting

Posted Date: April 13th, 2021

DOl: https://doi.org/10.21203/rs.3.rs-409258/v1

License: (c) (i) This work is licensed under a Creative Commons Attribution 4.0 International License.

Read Full License 


\section{Abstract}

\section{Background}

Tracheal intubation in an out-of-hospital setting is a frequent and potentially difficult procedure. The risk of adverse events increases dramatically with the number of attempts. The failure rate of the first intubation attempt ranges from 5 to $32 \%$ and the risk factors are unclear. We evaluated the failure rate of the first intubation attempt in an out-of-hospital setting and identified variables potentially associated with such failure.

\section{Methods}

This was an observational prospective multicenter study performed over 17 months and involving 10 prehospital emergency medical units. Airway management for patients who needed tracheal intubation followed the national guidelines. Rapid sequence intubation with a sedative and myorelaxant drugs was systematically performed for spontaneously breathing patients. After each tracheal intubation, the operator was required to provide, by completing a data-collection form, information on operator and patient characteristics and the environmental conditions during the intubation. The primary endpoint was failure of the first intubation attempt.

\section{Results}

During the study period, 1546 patients were analyzed, of whom $59 \%$ had cardiac arrest, and 486 intubations failed on the first attempt (31.4\% [95\% confidence interval $=30.2-32.6])$. A multivariate analysis revealed that the following 7 of 28 factors were associated with an increased risk of a failed first intubation attempt: operator with fewer than 50 prior intubations, small inter-incisor space, limited extension of the head, macroglossia, ear/nose/throat tumor, cardiac arrest, and vomiting. The frequency of adverse events was $13.4 \%$ and increased with each additional attempt.

\section{Conclusions}

The failure rate of the first attempt was high. Most risk factors could be identified only at the moment of occurrence and were not easily anticipated. Finally, the risk of complications increased with the number of attempts.

\section{Introduction}

Tracheal intubation $(\mathrm{TI})$ is a procedure that is frequently performed in an out-of-hospital emergency setting. TI is associated with a risk of adverse events, including severe sequelae such as hypoxemia, vomiting, aspiration, hypotension, and cardiac arrest [1-5]. The risk of adverse events increases dramatically with the number of intubation attempts $[3,4,6]$. Thus, it is important that the first intubation attempt succeeds. In most cases, the environment in an out-of-hospital setting is not appropriate for intubation, and can be austere (outside, restricted space, patient on the floor, or public place) or 
dangerous (mountain, sea, or roadside) [7]. Although literature data are abundant, they are extremely heterogenous. Indeed, the available studies differ in terms of operator profiles, TI indications, and design. Based on studies involving management by physician-led teams in out-of-hospital settings and for which data are available, the failure rate of the first intubation attempt ranges from $5 \%$ to $32 \%$ [8-22] (Table 1). Numerous variables are associated with difficult intubation (DI), such as more than two attempts and bad glottic visualization, but few studies have analyzed risk factors for failure of the first attempt $[8,12,17$, 23-25]. Identification of such factors would decrease the risk of complications.

We evaluated the failure rate of the first intubation attempt in an out-of-hospital setting and identified variables potentially associated with such failure.

\section{Methods}

\section{Design}

This was an observational prospective multicenter study performed between March 1, 2017 and August 31, 2018 involving 10 mobile emergency medical units in France. The study design complied with the recommendations of the STROBE initiative [26].

The French EMS handles all calls made to a single nationwide emergency telephone number (\#15). Physicians responding to the calls evaluate the type of assistance required and dispatch an ambulance manned by an emergency physician, a nurse with training in intensive care (occasionally an anesthetist nurse), and a driver with first-aid experience [27]. The vehicles carry resuscitation equipment and drugs, including sedatives and analgesics [27].

Based on the information available, the publication group of the ethics committee of the university hospital has approved publication of this work (GP-CE 2020-10). Written information was provided to each patient and/or their relatives. All data were anonymized and protected.

\section{Patients and data collection}

All patients $\geq 15$ years old and intubated in an out-of-hospital setting were included in the analysis. For each intubation, the operators were required to follow the national guidelines. For patients with spontaneous breathing, rapid sequence induction with a sedative drug and a myorelaxant drug (succinylcholine or rocuronium) was performed [28].

After each tracheal intubation, the operator completed a form divided into three parts (Additional file 1). The first part concerned the operator (function and experience with intubation). The second part concerned the patient and included demographic data, main indication for intubation, and any anatomical or circumstantial factor that may be a source of difficulty in intubation. The third part concerned the conditions during intubation: the position of the operator, the position of the patient, and the environment. 


\section{Outcome}

The primary endpoint was the failure of the first intubation attempt. An attempt was defined as one advancement of the tube in the direction of the glottis during direct laryngoscopy.

The secondary endpoints were the Intubation Difficulty Scale score (IDS) [29], the Cormack-Lehane laryngoscopy view score [30], variables associated with the failed first attempt, and adverse events during or immediately after intubation. A score of $>5$ on the IDS indicates a DI [16, 24, 29].

\section{Statistical analysis}

We considered all variables that are known to be associated with failure of a first intubation attempt or with $\mathrm{DI}$, as well as those suspected of being associated with a failed first attempt. Variables of interest concerned operator and patient characteristics, indication for $\mathrm{Tl}$, environment, and position of the patient and of the operator during intubation (Additional file 1) [8, 12, 17, 23-25].

Normally distributed (verified by Kolmogorov-Smirnov test and Shapiro-Wilk test) quantitative variables are expressed as means and standard deviations and were compared by Student's $t$-test. All other variables are expressed as medians and 25th and 75th percentiles (interquartile range) and were compared by Mann-Whitney non-parametric test. Qualitative variables are expressed as percentages and 95\% confidence intervals (Cls) and were compared by chi-squared test, corrected Yates test, or Fisher test, as indicated. To identify variables independently associated with failure of the first intubation attempt, a multivariate analysis adjusted for sex, age, center, and variables with a p-value $\leq 0.2$ in univariate analyses, was conducted using a backward step-by-step logistic regression model. The associations are expressed as odds ratios (ORs) with $95 \%$ Cls. The goodness of fit of the model was assessed by the Hosmer-Lemeshow test. Data were entered into EpiData 3.0 software, and statistical analysis was performed using SPSS version 26.0 software (IBM, SPSS Inc., Chicago, IL).

\section{Sample size calculation}

Sample size was calculated based on data from the literature. The failure rate of the first attempt is around $16 \%$ [11], varying between 5 and $32 \%[8,9]$. With an accuracy of $2 \%$, and a risk a of $5 \%$, the required number of patients was 1290 , plus $10 \%$ to compensate for loss to follow up. Therefore, at least 1419 patients were required.

\section{Results}

Overall, 1819 patients were intubated by the EMS during the study period. Of these, we analyzed 1546 patients (Figure 1). Four hundred and eighty-six intubations $(31.4 \% ; 95 \% \mathrm{Cl}=30.2-32.6)$ failed on the first attempt.

Table 2 lists the main characteristics of the operators. The operators estimated that their experience with intubation was good or very good, moderate, or weak in 62,25 , and $11 \%$ of cases, respectively. Of the 
operators, $54 \%$ had performed at least 50 intubations.

Table 3 lists the main characteristics of the patients. Of the 916 cardiac arrest intubations (59.2\%), 857 were realized without rapid sequence induction and 59 patients who had returned to spontaneous circulation before intubation received rapid sequence induction. Among the 163 patients with severe trauma, 55 (33.7\%) experienced a cardiac arrest.

Among the 1546 intubation attempts, the rates of Cormack-Lehane scores of 1, 2, 3, and 4 were $52.1 \%$, $26.9 \%, 15.0 \%$, and $5.8 \%$, respectively. Two cases were missing a Cormack-Lehane score: one was associated with impossible intubation, and the other had an IDS score of 7. In total, 196 intubation attempts $(12.7 \% ; 95 \% \mathrm{Cl}=11.1-14.3)$ had an IDS score of $>5$. Of 19 attempts to intubate through a laryngeal mask, 1 failed. In the failed case, ventilation was possible using a laryngeal mask.

The techniques used to improve intubation were external laryngeal pressure in $29 \%$ of cases $(N=449)$, a bougie in $15.3 \%(\mathrm{~N}=236)$, and a stylet in $10.1 \%$ of cases $(\mathrm{N}=156)$. The blade and/or the patient's head position were changed in $4.7 \%$ and $3.3 \%$ of the cases, respectively. A laryngeal mask was used in $1.2 \%$ of the cases $(N=19)$, nasal intubation in $0.2 \%(N=3)$, and a video laryngoscope in $0.1 \%(N=2)$. These techniques were used alone or in combination.

Two hundred and seven patients (13.4\%) had at least one adverse event during or immediately after tracheal intubation. Among non-cardiac arrest patients $(\mathrm{N}=629), 93(14.8 \%)$ had at least one adverse event, comprising 45 oxygen desaturation, 35 esophageal intubations, 9 vomiting, 5 cardiac arrest, 1 tooth trauma, and 3 laryngospasms. The frequency of adverse events was $8.9 \%$ (33/371) in patients who were intubated on the first attempt and 43\% (58/134) in those who required more than one attempt $(p=$ 0.0001). Among the patients who experienced cardiac arrest, the frequency of adverse events was $4.4 \%$ $(23 / 520)$ in those intubated at the first attempt and 35.2\% (92/261) in those in whom the first attempt failed $(p=0.0001)$. Figure 2 shows the complication rates according to the number of intubation attempts.

Univariate analyses of 28 variables identified 24 variables for multivariate analysis (Table 4). Three variables were obvious confounders: operator function, operator experience level, and number of prior intubations. Indeed, $75 \%$ of anesthetist nurses (ANs) or postgraduate physicians (PGPs) $>2$ years (663/883 intubations) had performed more than 50 intubations, versus $25 \%$ for the other operators (156/625 intubations). Similarly, $79.4 \%$ of operators with good to very good experience (746/940 intubations) had conducted more than 50 intubations, versus $12.4 \%$ for the other operators $(69 / 556$ intubations). Therefore, we included the number of prior intubations in the multivariate analysis.

Among patients who experienced cardiac arrest, chest compression was continued during intubation in 439 patients, with a first-attempt failure rate of $41.9 \%$. Chest compression was stopped in 413 patients, with a first-attempt failure rate of $27.4 \%(p<0.0001)$. 
A multivariate analysis was conducted for 1346 cases on the totality of the data, 935/1082 (86.4\%) cases with one intubation attempt, and 398/486 (84.6\%) cases with more than one intubation attempt. The multivariate analysis was adjusted for sex, age, and center. The final model (Hosmer-Lemeshow test, $p=0.4$ ) included 12 variables, 7 of which were significantly associated with the risk of a failed firstattempt intubation: $\leq 50$ previous intubations, inter-incisor space $<2$ fingerbreadths, cardiac arrest as an indication for intubation, limited extension of the head, macroglossia, vomiting, and ENT tumor (Table 5). Three centers had a lower risk of failure than the other centers.

\section{Discussion}

The prevalence of a failed first intubation attempt was $31.4 \%(95 \% \mathrm{Cl}=30.2-32.6)$ among patients managed in an out-of-hospital setting. The following variables were independently associated with a failed first intubation attempt, operator with $\leq 50$ prior intubations, small inter-incisor space, limited head extension, macroglossia, ENT tumor, cardiac arrest, and vomiting.

A prior meta-analysis indicated a significant difference in the success rate of the first intubation attempt with rapid sequence induction in an out-of-hospital setting between physician and non-physician operators $(88 \%$ [95\% $\mathrm{Cl}=83-93 \%]$ and $78 \%$ [95\% $\mathrm{Cl}=65-89 \%]$, respectively [1]. The eight studies on physicians in that analysis were heterogeneous: two retrospective $[20,21]$ and four prospective $[13,14$, $18,19]$ observational studies, one controlled trial [9], and one study concerning head trauma only [10] (Table 1). In studies of management by physician-led teams in an out-of-hospital setting and involving patients who had and had not experienced cardiac arrest, the failure rate of the first intubation attempt was $12.6-32 \%[8,12,15-18]$ (Table 1). Adnet et al. published a prospective multicenter observational study in 1998 involving 691 patients, which showed a failure rate of the first intubation attempt of 32\% [8]. Two later observational studies involving only anesthesiologists yielded failure rates of $12.6 \%$ and $22.4 \%$ [12, 18]. However, $70 \%$ and $20 \%$ and $20 \%$ and $54 \%$ in the first and second studies, respectively, had trauma and cardiac arrest $[12,18]$. In an analysis of 2674 patients, Combes et al. reported a failure rate of $26 \%$ and another study of 653 intubations a rate of $29.9 \%[15,17]$. In these two studies, the main operators were emergency physicians, but intubations were also performed by residents or anesthetist nurses under the supervision of the physician. A prospective multicenter study analyzed 1941 intubations managed by paramedics, nurses or physicians, a priori [31]. Paramedics performed $94 \%$ of the intubations and the first-attempt failure rate was $31.5 \%$. These observational studies were largely similar to this work. A randomized multicenter trial in an out-of-hospital setting showed a failure rate of $28.8 \%$ [16]. Our results are, therefore, similar to those of other studies (Table 1).

Numerous variables are associated with DI, defined as more than two intubation attempts or bad glottic visualization. However, few studies analyzed those associated with first-attempt failure. The seven variables we identified were similar to those for DI [12,17, 23-25], the exceptions being operator status (resident), maxillofacial trauma, history of ENT tumor, body mass index (BMI), operator position [24], patient on the floor, hyoid-mental length less than three fingerbreadths, airway obstruction [17], blood, secretion or vomit in the upper airway, anatomical factors, patient position, and bright ambient light [12]. 
Most of these variables-inter-incisor space, macroglossia, limited extension of the head, ENT tumor and maybe vomiting-cannot be foreseen. This hampers prediction of DI.

The risk of first-attempt failure is higher for operators with experience of fewer than 50 intubations [24, 32]. Moreover, the survival rate is higher among patients with cardiac arrest intubated by rescuers with more than 50 prior intubations, and among non-cardiac arrest patients intubated by rescuers with more than 26 prior intubations [33]. A review of the literature concluded that at least 50 intubations with no more than two intubation attempts are necessary to obtain a $90 \%$ success rate [34]. Emergency physicians perform a median of 10 intubations per year and $25 \%$ perform four or fewer intubations per year [35]. Among 5,245 out-of-hospital rescuers, $>67 \%$ had performed two or fewer Tls and $>39 \%$ had never performed $\mathrm{TI}[36]$. A retrospective study involving intensive-care paramedics trained in the management of vital distress reported a failure rate of the first intubation attempt of $10.6 \%$ [37]. This highlights the importance of the initial training of rescuers, who are likely to be confronted with vital distress. Also, in this study all patients with spontaneous breathing received sedative and myorelaxant drugs. However, paramedics cannot administer curare. This could explain some of the reported risk factors, e.g., clenched jaw, trismus, inability to pass the endotracheal tube through the vocal cords, and an intact gag reflex $[25,36]$.

Cardiac arrest was a risk factor for failure of the first intubation attempt. Timermann et al. showed that intubation difficulty is more frequent in patients with cardiac arrest $(17 \%$ vs. $<10 \%)$ but neither Combes et al. nor Freund et al. found such an association $[11,17,24]$. One possible explanation is continuation of cardiopulmonary resuscitation during intubation in $>50 \%$ of patients.

BMI was not a risk factor for failure, contrary to prior reports [24, 38, 39]. In a study similar to ours, BMI was associated with $\mathrm{DI}(\mathrm{OR}=1.0[95 \% \mathrm{Cl}=1.0-1.1])$ [24]. In this study, the dependent variable was $\mathrm{DI}$ (frequency, $7 \%$ ), defined as an IDS $>5$ [24]. In a retrospective analysis involving paramedics, a BMI $\geq$ $40 \mathrm{~kg} \cdot \mathrm{m}^{-2}$ was significantly associated with $\mathrm{DI}(\mathrm{OR}=3.68[95 \% \mathrm{Cl}=1.3-10.6]$ [38]. However, the body weight of $39 \%$ of the patients was not available and the multivariate analysis was adjusted for only age, sex, pathology, and BMI [38]. In the emergency department (ED), obese patients $(N=342)$ had a failure rate of the first intubation attempt of $40.7 \%$ vs. $29.1 \%$ for leaner patients $(N=5370)$ (adjusted OR $=0.62$ [95\% $\mathrm{Cl}=0.49-0.79]$ ] [39]. Obesity remains a controversial risk factor for $\mathrm{Dl}$; therefore, caution is required when intubating obese patients in emergency settings.

The overall rate of adverse events was $>13 \%$, and significantly increased with the number of intubation attempts. This result is consistent with prior studies in out-of-hospital settings or in the emergency department $[4,6,8]$. Indeed, Adnet et al. reported an incidence of mechanical complications of $12.2 \%$ and general complications of $12.3 \%$ in an out-of-hospital setting; complications were associated with a significantly higher number of intubation attempts [8]. In an emergency department, the incidence of adverse events was $14.2 \%$, increasing to $47.2 \%, 63.6 \%$, and $70.6 \%$ after two, three, and four or more intubation attempts, respectively [4]. This is consistent with a previous report of adverse event rates for two attempts or fewer and three attempts or more of $9 \%$ and $35 \%$, respectively [6]. 
Overall, the failure rate of the first intubation attempt was high. Some of the associated factors can be improved (operator training and experience), but most cannot. A randomized control trial performed in an emergency department showed that systematic use of a bougie during the first intubation attempt improved the success rate [40]. However, a secondary analysis of a study conducted in an out-of-hospital setting involving paramedics found no significant difference according to bougie use [41].

\section{Limitations}

Several limitations of this study should be discussed. This study was subject to self-reporting bias, possibly leading to underestimates of intubation difficulties. Real-time independent monitoring of the airway is complex in an out-of-hospital setting; although we requested and expected real-time data entry by operators, this did not always occur. Three centers had a significantly lower failure rate than the other centers. This was associated with the operator, who was more frequently a physician with $>2$ years of experience (Additional file 2). We took this into account by adjusting for center in the multivariate analysis.

This study was conducted in 10 prehospital departments, all of which performed the procedures according to the national guidelines. So, the results are applicable to similar emergency prehospital units. However, it was performed in a prehospital emergency medical system, and the findings cannot be generalized to other non-medical prehospital systems. Nevertheless, knowledge of the risk factors associated with difficult airway management in an out-of-hospital emergency setting can help nonphysician operators to improve their practice and anticipate DI.

Additionally, the follow-up of adverse events was limited to out-of-hospital management; it is possible that some adverse events, such as aspiration-mediated pulmonary complications, endotracheal tube dislodgement, or pneumothorax, were not captured. Moreover, the rate of adverse events may have been underestimated in patients with a successful first intubation attempt. We believe the large multicenter sample accurately represents the airway management practices in an out-of-hospital setting.

\section{Conclusion}

In this multicenter study, the first intubation attempt failed in more than $30 \%$ of patients. Seven variables were associated with an increased risk of failure, and most of them were not foreseeable. The rate of complications during or immediately after intubation increased dramatically with the number of attempts. We plan to explore means of minimizing the rate of a failed first intubation attempt by, for example, improving operator training and the use of several items of equipment during intubation (for example, a bougie).

\section{Abbreviations}


TI: Tracheal intubation; EMS: Emergency Medical System; STROBE: Strengthening the Reporting of Observational studies in Epidemiology; IDS: Intubation Difficulty Scale score; DI: Difficult Intubation; ENT: Ears - Nose - Throat; PGP: Postgraduate Physician; AN: Anesthetist Nurse; ANS: Anesthetist Nurse Student BMI: Body Mass Index. RSI: Rapid Sequence Induction

\section{Declarations}

\section{Ethics approval and consent to participate}

The locally appointed ethics committee (Publication group of the ethics committee of the university hospital of Bordeaux) has approved publication of this work (GP-CE 2020-10). Written information was provided to each patient and/or their relatives. All data were anonymized and protected. Need for written consent was waived, as the study collected anonymized data. The study design complied with the recommendations of the STROBE initiative.

\section{Consent for publication}

Not applicable

\section{Availability of data and materials}

The datasets used and/or analyzed during the current study are available from the corresponding author on reasonable request.

\section{Competing interests}

The authors declare that they have no competing interests

\section{Funding: none}

\section{Authors contributions}

MG, CGJ, and BS conceived the study, designed the trial. MG, MW, RB and BS supervised the conduct of the trial and data collection. MG, PC and CGJ undertook recruitment of participating centers. RB, PGR, $\mathrm{MR}, \mathrm{GD}, \mathrm{GB}, \mathrm{ED}, \mathrm{JB}, \mathrm{JPL}, \mathrm{SG}, \mathrm{KM}$ undertook recruitment of patients and managed the data, including quality control. MG, PC and CGJ analyzed the data. MG drafted the manuscript, and all authors contributed substantially to its revision. MG takes responsibility for the paper as a whole.

\section{Acknowledgements}

The authors acknowledge the sponsor, Bordeaux University Hospital, the patients, physicians, and nurses who participated in the study.

The English in this document has been checked by at least two professional editors, both native speakers of English. For a certificate, please see: http://www.textcheck.com/certificate/KmZtld 


\section{References}

1. Fouche P, Stein C, Simpson P, Carlson JN, Doi SA. Non physician out-of-hospital rapid sequence intubation success and Adverse Events: A Systematic Review and Meta-Analysis. Ann Emerg 2017;70:449-459.

2. Jabre P, Avenel A, Combes X, Kulstad E, Mazariegos I, Bertrand L, et al. Morbidly related to emergency endotracheal intubation - a substudy of the KETAmine SEDation trial. Resuscitation. 2011;82 (5):517-522.

3. Mort Emergency tracheal intubation: complications associated with repeated laryngoscopic attempts. Anesth Analg. 2004;99(2):607-13

4. Sakles JC, Chiu S, Mosier J, Walker C, Stolz The importance of first pass success when performing orotracheal intubation in the emergency department. Acad Emerg Med. 2013;20 (1):71-78.

5. Brown CA III, Bair AE, Pallin DJ,Walls RM. Techniques, success, and adverse events of emergency department adult intubations. Ann Emerg Med. 2015;65(4):363-370.

6. Hasegawa K, Shigemitsu K, Hagiwara Y, Chiba T, Watase H, Brown III CA, et al. Association between repeated intubation attempts and adverse events in emergency departments: an analysis of a multicenter prospective observational study. Ann Emerg Med 2012;60:749-754

7. Pepe PE, Copass MK, Joyce Prehospital endotracheal intubation: rationale for training emergency medical personnel. Ann Emerg Med. 1985;14(11):1085-92.

8. Adnet F, Jouriles NJ, Le Toumelin P, Hennequin B, Taillandier C, Rayeh F, et al. Survey of out-ofhospital emergency intubations in the French prehospital medical system: a multicenter study.Ann Emerg Med 1998;32:454-460

9. Smith CE, Kovach B, Polk JD, Hagen JF, Fallon WF. Prehospital tracheal intubating conditions during rapid sequence intubation: Rocuronium versus Vecuronium. Air Med J 2002;21:26-32

10. Grmec S, Mally S. Prehospital determination of tracheal tube placement in severe head injury. Emerg Med J 2004;21:518-520.

11. Timmermann A, Eich C, Russo SG, Natge U, Bräuer A, Rosenblatt WH, et al. Prehospital airway management: a prospective evaluation of anaesthesia trained emergency physicians. Resuscitation 2006;70:179-185

12. Helm M, Hossfeld B, Schafer S, Hoitz J, Lampl L. Factors influencing emergency intubation in the prehospital setting - a multicenter study in the german helicopter emergency medical service. $\mathrm{Br} \mathrm{J}$ Anaesth 2006;96:67-71.

13. Nakstad AR, Heimdal HJ, Strand T, Sandberg M. Incidence of desaturation during prehospital rapid sequence intubation in a physician-based helicopter emergency service. Am J Emerg Med 2011;9:639-644. 14 Harris T, Lockey D. Success in physician prehospital rapid sequence intubation: what is the effect of base speciality and length of anaesthetic training? Emerg Med J 2011;28:225229. 
14. Harris T, Lockey D. Success in physician prehospital rapid sequence intubation: what is the effect of base speciality and length of anaesthetic training? Emerg Med J 2011;28:225-229.

15. Combes X, Jabre P, Margenet A, Merle JC, Leroux B, Dru M, et al. Unanticipated difficult airway management in the prehospital emergency setting. Prospective validation of an algorithm. Anesthesiology 2011;114:105-10

16. Jabre P, Galinski M, Ricard-Hibon A, Devaud ML, Ruscev M, Kulstad E, et al. Out-of-hospital tracheal intubation with single-use versus reusable metal laryngoscope blades: a multicenter randomized controlled trial. Ann Emerg Med 2011;57:225-231

17. Freund $Y$, Duchateau FX, Devaud ML et Factors associated with difficult intubation in prehospital emergency medicine. Eur J Emerg Med. 2012; 19(5): 304-8.

18. Rognas L, Hansen TM, Kirkegaard H, Tonnesen E. Pre-hospital advanced airway management by experienced anaesthesiologists : a prospective descriptive study. Scand J Trauma Resusc Emerg Med 2013;21:58 doi :10.1186/1757-7241-21-84

19. Helm M, Kremers L, Lampl L, Hossefeld B. Incidence of transient hypoxia during pre-hospital rapid sequence intubation by anaesthesiologists. Acta Anaesthesiol Scand 2013;57:199-205

20. Soti A, Temesvari P, Hetzman L, Eross A, Petroczy A. Implementig new advances airway management standards in the Hungarian physician staffed helicopter emergency medical service. Scand $\mathrm{J}$ Trauma Resusc Emerg Med 2015 ;23:3 doi: 10.1186/s13049-014-0081-z

21. Peters J, van Wageningen B, Hendriks I, Eijk R, Edwards M, Hoogerwerf N, et al. First-pass intubation success rate during rapid sequence induction of prehospital anaesthesia by physicians versus paramedics. Eur J Emerg Med 2015;22:391-394

22. Sunde GA, Heltne JK, Lockey D, Burns B, Sandberg M, Fredriksen K, et al. Airway management by physician-staffed Helicopter Emergency Medical Services-a prospective, multicentre, observational study of 2327 patients. Scand J Trauma Resusc Emerg Med. 2015; 23:57

23. Wang HE, Kupas DF, Paris PM, Bates RR, Costantino JP, Yealy DM. Multivariate predictors of failed prehospital endotracheal intubation. Acad Emerg Med 2003;10:717-724

24. Combes X, Jabre P, Jbeilli C, Leroux B, Bastuji-Garin S, Margenet A, et al. Airway management : incidence and risk factors od difficult airway. Acad Emerg 2006; 13(8):828-34.

25. Carlson JN, Hostler D, Guyette FX, Pinchalk M, Martin-Gil C. Derivation and validation of the prehospital difficult airway identification tool (PreDAIT): A predictive model for difficult West $\mathrm{J}$ Emerg Med. 2017; 18(4): 662-72.

26. von Elm E, Altman DG, Egger M, Pocock SJ, Gotzsche PC, Vandenbroucke JP, STROBE initiative. The strengthening the Reporting of observational Studies in Epidemiology (STROBE) statement: Guidelines for reporting observational studies. J Clin Epidemiol. 2008;61:344-34

27. Adnet F, Lapostolle F. International EMS: France. Resuscitation 2004;63:7-9.

28. Vivien B, Adnet F, Bounes V, Cheron G, Combes X, David JS, et al. Recommandations formalisées d'Experts 2010: Sédation et analgésie en structure d'urgence (Réactualisation de la conférence d'expert de la SFAR de 1999. Ann Fr Anesth Réanim 2010;31:391-404. 
29. Adnet F, Borron SW, Racine SX et The intubation difficulty scale (IDS): proposal and evaluation of new score characterizing the difficulty of endotracheal intubation. Anesthesiology. 1997; 87: 1290 -7.

30. Cormack RS, Lehane J. Difficult tracheal intubation in obstetrics. Anaesthesia 1984;39:1105-1111

31. Wang HE and Yealy DM. How many attempts are required to accomplish out-of-hospital endotracheal intubation. Acad Emerg Med 2006;13:372-377.

32. Dyson K, Bray JE, Smith K, Bernard S, Straney L, Nair R, et al. Paramedic Intubation Experience Is Associated with Successful Tube Placement but Not Cardiac Arrest Survival. Ann Emerg Med. $2017 ; 70: 382-390$

33. Wang HE, Balasubramani GK, Cook LJ, Lave JR, Yealy DM. Out-of-hospital endotracheal intubation experience and patient outcomes. Ann Emerg Med 2010;55:527-537

34. Buis ML, Maissan IM, Hoeks SE, Klimek M, Stolker RJ. Defining the learning curve for endotracheal intubation using direct laryngoscopy: A systematic Resuscitation 2016; 99: 63-71

35. Carlson JN, Zocchi M, Marsh K, McCoy C, Pines JM, Christensen A, et al. Procedural experience with intubation: results from a national emergency medicine group. Ann Emerg Med 2019;74:786-794.

36. Wang HE, Kupas DF, Hostler D, Cooney R, Yealy DM, Lave JR. Procedural experience with out-ofhospital endotracheal intubation. Crit Care Med 2005;33:1718-1721

37. Delorenzo A, St Clair T, Andrew E, Bernard S, Smith K. Prehospital Rapid Sequence Intubation by Intensive Care Flight Prehosp Emerg Care 2018;22:595-601

38. Holmberg TJ, Bowman SM, Warner KJ, Vavilala MS, Bulger EM, Copass MK, et al. The association between obesity and difficult prehospital tracheal intubation. Anesth Analg 2011;112:1132

39. Yakushiji H, Goto T, Shirasaka W, Hagiwara Y, Watase H, Okamoto H, et al. Association of obesity with tracheal intubation success on first attempt and adverse events in the emergency department: an analysis of the multicenter prospective observational study in Japan. PLoS One $2018 \mathrm{Apr}$ 19;13(4): doi: 10.1371/journal.pone.0195938. eCollection 2018

40. Driver BE, Prekker ME, Klein LR, Reardon RF, Miner JR, Fagerstrom ET, et al. Effect of use a bougie vs endotracheal tube and stylet on first-attempt intubation success among patients with difficult airways undergoing emergency intubation. A randomized clinical trial. JAMA 2018;319:2179-2189

41. Bonnette AJ, Aufderheide TP, Jarvis JL, Lesnick JA, Nichol G, Carlson JN, et al. Bougie-assisted endotracheal intubation in the pragmatic airway resuscitation trial. Resuscitation (2020) doi: https://doi.org/10.1016/j.resuscitation.2020.11.003

\section{Tables}

Table 1: Studies of management by out-of-hospital physician-led teams for which data on the first intubation attempt were available. 


\begin{tabular}{|c|c|c|c|c|c|}
\hline $\begin{array}{l}1^{\text {st }} \\
\text { Author/year/ } \\
\text { Ref }\end{array}$ & Study & Population & Operator & $\mathbf{N}$ & $\begin{array}{l}\text { Failure } \\
\text { rate of } 1^{\text {st }} \\
\text { attempt } \\
(\%)\end{array}$ \\
\hline $\begin{array}{l}\text { Adnet } 1998 \\
\text { (8) }\end{array}$ & $\begin{array}{l}\text { Observational } \\
\text { prospective } \\
\text { Aim: DI rate }\end{array}$ & $\begin{array}{l}\text { RSI and } \\
\text { non-RSI }\end{array}$ & $\begin{array}{l}\text { Emergency } \\
\text { physicians, } \\
\text { residents, } \\
\text { anesthetist } \\
\text { nurses }\end{array}$ & $\begin{array}{l}\mathrm{N}=691 \\
\text { Cardiac arrest: } \\
48 \%\end{array}$ & 32 \\
\hline $\begin{array}{l}\text { Smith } 2002 \\
\text { (9) }\end{array}$ & $\begin{array}{l}\text { RCT } \\
\text { Rocuronium vs. } \\
\text { vecuronium }\end{array}$ & RSI only & $\begin{array}{l}\text { Emergency } \\
\text { physicians }\end{array}$ & $N=100$ & 29 \\
\hline $\begin{array}{l}\text { Grmec } 2004 \\
(10)\end{array}$ & $\begin{array}{l}\text { Observational } \\
\text { prospective } \\
\text { TI modalities } \\
\text { confirmations }\end{array}$ & $\begin{array}{l}\text { RSI only } \\
\text { Trauma }\end{array}$ & $\begin{array}{l}\text { Emergency } \\
\text { physicians }\end{array}$ & $N=81$ & 10 \\
\hline $\begin{array}{l}\text { Timermann } \\
2006(11)\end{array}$ & $\begin{array}{l}\text { Observational } \\
\text { prospective } \\
\text { Aim: DI rate }\end{array}$ & $\begin{array}{l}\text { RSI and } \\
\text { non-RSI }\end{array}$ & $\begin{array}{l}\text { Emergency } \\
\text { physicians }\end{array}$ & $\begin{array}{l}\mathrm{N}=982 \text { OTI } \\
\text { Cardiac arrest: } \\
50 \% \\
\text { Trauma: } 26 \%\end{array}$ & 16.2 \\
\hline $\begin{array}{l}\text { Helm } 2006 \\
\text { BJA (12) }\end{array}$ & $\begin{array}{l}\text { Observational } \\
\text { prospective } \\
\text { Aim: success rate } \\
\text { and } \\
\text { complications of } \\
\text { TI }\end{array}$ & $\begin{array}{l}\text { RSI and } \\
\text { non-RSI }\end{array}$ & $\begin{array}{l}\text { Anesthetist } \\
\text { physicians }\end{array}$ & $\begin{array}{l}\mathrm{N}=342 \\
\text { Cardiac arrest: } \\
20 \% \\
\text { Trauma }=70 \%\end{array}$ & 12.6 \\
\hline $\begin{array}{l}\text { Nakstad } \\
2011 \\
(13)\end{array}$ & $\begin{array}{l}\text { Observational } \\
\text { prospective } \\
\text { Aim: } \\
\text { Desaturation rate }\end{array}$ & RSI only & $\begin{array}{l}\text { Emergency } \\
\text { physicians }\end{array}$ & $\begin{array}{l}\mathrm{N}=122 \\
\text { Trauma: } 65 \%\end{array}$ & 11 \\
\hline $\begin{array}{l}\text { Harris } 2011 \\
(14)\end{array}$ & $\begin{array}{l}\text { Observational } \\
\text { prospective } \\
\text { Aim: number of } \\
\text { attempts } \\
\text { to success TI }\end{array}$ & RSI only & $\begin{array}{l}\text { Emergency } \\
\text { physicians } \\
\text { Training }<6 \\
\text { months } \\
\text { vs. }>6 \mathrm{M}\end{array}$ & $N=402$ & 12.5 \\
\hline $\begin{array}{l}\text { Combes } \\
2011 \\
(15)\end{array}$ & $\begin{array}{l}\text { Observational } \\
\text { prospective }\end{array}$ & $\begin{array}{l}\text { RSI and } \\
\text { non-RSI }\end{array}$ & $\begin{array}{l}\text { Emergency } \\
\text { physicians, } \\
\text { residents, }\end{array}$ & $N=2674$ & 26 \\
\hline
\end{tabular}




\begin{tabular}{|c|c|c|c|c|c|}
\hline & $\begin{array}{l}\text { Management of } \\
160 \mathrm{DI}\end{array}$ & & $\begin{array}{l}\text { Anesthetist } \\
\text { nurses }\end{array}$ & & \\
\hline $\begin{array}{l}\text { Jabre } 2011 \\
(16)\end{array}$ & $\begin{array}{l}\text { Controlled } \\
\text { randomized trial. } \\
\text { Reusable vs. } \\
\text { single-use } \\
\text { laryngoscope } \\
\text { blade } \\
\text { Aim: success of } \\
\text { first attempt }\end{array}$ & $\begin{array}{l}\text { RSI and } \\
\text { non-RSI }\end{array}$ & $\begin{array}{l}\text { Emergency } \\
\text { physicians, } \\
\text { residents, } \\
\text { anesthesia nurses }\end{array}$ & $\begin{array}{l}\mathrm{N}=817 \\
\text { Cardiac arrest: } \\
51 \%\end{array}$ & 28.8 \\
\hline $\begin{array}{l}\text { Freund } 2012 \\
\text { (16) (17) }\end{array}$ & $\begin{array}{l}\text { Observational } \\
\text { prospective } \\
\text { Aim: DI rate }\end{array}$ & $\begin{array}{l}\text { RSI and } \\
\text { non-RSI }\end{array}$ & $\begin{array}{l}\text { Emergency } \\
\text { physicians } \\
\text { residents, } \\
\text { anesthesia nurses }\end{array}$ & $\begin{array}{l}\mathrm{N}=653 \\
\text { Cardiac arrest: } \\
56 \%\end{array}$ & 29.9 \\
\hline $\begin{array}{l}\text { Rognas } \\
2013 \\
(18)\end{array}$ & $\begin{array}{l}\text { Observational } \\
\text { prospective } \\
\text { Aim: DI rate: > } 1 \\
\text { attempt } \\
\text { Complication } \\
\text { rate }\end{array}$ & $\begin{array}{l}\text { RSI and } \\
\text { non-RSI }\end{array}$ & $\begin{array}{l}\text { Anesthetist } \\
\text { physicians }\end{array}$ & $\begin{array}{l}\mathrm{N}=683 \\
\text { Cardiac arrest: } \\
54 \% \\
\text { Complications: } \\
14 \%\end{array}$ & 22.4 \\
\hline $\begin{array}{l}\text { Helm } 2013 \\
\text { (19) }\end{array}$ & $\begin{array}{l}\text { Observational } \\
\text { prospective } \\
\text { Aim: } \\
\text { desaturation rate }\end{array}$ & RSI only & $\begin{array}{l}\text { Emergency } \\
\text { physicians }\end{array}$ & $N=150$ & 8 \\
\hline $\begin{array}{l}\text { Soti } 2015 \\
(20)\end{array}$ & $\begin{array}{l}\text { Observational } \\
\text { retrospective } \\
\text { Aim: Attempt } \\
\text { number }\end{array}$ & RSI only & $\begin{array}{l}\text { Emergency } \\
\text { physicians }\end{array}$ & $N=433$ & 5 \\
\hline $\begin{array}{l}\text { Peters } 2015 \\
(21)\end{array}$ & $\begin{array}{l}\text { Observational } \\
\text { retrospective } \\
\text { Aim: success of } \\
\text { first attempt }\end{array}$ & RSI only & $\begin{array}{l}\text { Physicians } \\
\text { Nurses } \\
\text { Paramedics }\end{array}$ & $\begin{array}{l}\text { N }=1399 \\
\text { Physicians: } \\
52 \% \\
\text { Nurses: } 7 \% \\
\text { Paramedics: } \\
41 \%\end{array}$ & $\begin{array}{l}\text { Phys: } 15.5 \\
\text { Nurs: } \\
41.7 \\
\text { Param: } \\
53.6\end{array}$ \\
\hline $\begin{array}{l}\text { Sunde } 2015 \\
(21)\end{array}$ & $\begin{array}{l}\text { Observational } \\
\text { Prospective, } \\
\text { multicenter, }\end{array}$ & RSI only & Physicians & $\begin{array}{l}\mathrm{N}=2144 \\
\text { Cardiac Arrest: } \\
42 \%\end{array}$ & $\begin{array}{l}\text { CA:20.0\% } \\
\text { RSI: } \\
11.0 \%\end{array}$ \\
\hline
\end{tabular}


Aim: Assessment

of airway

management.

RSI: rapid sequence induction; DI: difficult intubation; TI: tracheal intubation; OTI: orotracheal intubation.

Table 2: Characteristics of the first operator for each intubation

\begin{tabular}{|c|c|c|c|c|c|c|c|}
\hline Function & Missing & Total & $\begin{array}{l}\text { PGP years } \\
>2\end{array}$ & $\begin{array}{l}\text { PGP years } \\
\leq 2\end{array}$ & Resident & AN & ANS \\
\hline $\mathrm{N}(\%)$ & 3 & 1543 & $836(54)$ & $325(21)$ & $\begin{array}{l}286 \\
(18.5)\end{array}$ & $\begin{array}{l}71 \\
(4.6)\end{array}$ & $\begin{array}{l}25 \\
(1.6)\end{array}$ \\
\hline $\begin{array}{l}\text { Previous } \\
\text { intubations, } \mathrm{N}(\%)\end{array}$ & 35 & 1511 & & & & & \\
\hline$<10$ & & $\begin{array}{l}47 \\
(3.1)\end{array}$ & $9(1.1)$ & $5(1.6)$ & $\begin{array}{l}32 \\
(11.4)\end{array}$ & 0 & $\begin{array}{l}1 \\
(4.0)\end{array}$ \\
\hline $10-20$ & & $\begin{array}{l}162 \\
(10.7)\end{array}$ & $29(3.6)$ & $78(24.4)$ & $\begin{array}{l}55 \\
(19.6)\end{array}$ & 0 & 0 \\
\hline $20-50$ & & $\begin{array}{l}481 \\
(31.9)\end{array}$ & $182(22.3)$ & $190(59.4)$ & $\begin{array}{l}107 \\
(38.2)\end{array}$ & 0 & $\begin{array}{l}1 \\
(4.0)\end{array}$ \\
\hline$>50$ & & $\begin{array}{l}821 \\
(54.3)\end{array}$ & $595(73.0)$ & $47(14.7)$ & $\begin{array}{l}86 \\
(30.7)\end{array}$ & $\begin{array}{l}70 \\
(100)\end{array}$ & $\begin{array}{l}23 \\
(92.0)\end{array}$ \\
\hline
\end{tabular}

PGP: postgraduate physician; resident: resident in training for anesthesia or emergency medicine; AN: anesthetist nurse; ANS: anesthetist nurse student.

Table 3: Patients' characteristics. 


\begin{tabular}{|c|c|}
\hline Variable & Entire cohort $(\mathrm{N}=1546)$ \\
\hline Age, median (IQR), y & $64(50-75)$ \\
\hline Range & $15-99$ \\
\hline \multicolumn{2}{|l|}{ Missing $N=12$} \\
\hline \multicolumn{2}{|l|}{ Sex, N (\%) } \\
\hline Men & $984(64.2)$ \\
\hline Women & $548(35.8)$ \\
\hline \multicolumn{2}{|l|}{ Missing $N=14$} \\
\hline Size, median (IQR), cm & $170.0(165-175)$ \\
\hline Range & $140-197$ \\
\hline \multicolumn{2}{|l|}{ Missing $N=172$} \\
\hline Weight, median (IQR), kg & $75(65-85)$ \\
\hline Range & $37-250$ \\
\hline \multicolumn{2}{|l|}{ Missing $N=55$} \\
\hline Body mass index, median (IQR), $\mathrm{kg} \cdot \mathrm{m}^{-2}$ & $25.0(22.8-28.3)$ \\
\hline Range & $13.8-70.3$ \\
\hline \multicolumn{2}{|l|}{ Missing $N=175$} \\
\hline \multicolumn{2}{|l|}{ Main indications of intubation, $\mathbf{N}(\%)$} \\
\hline \multicolumn{2}{|l|}{ Missing $N=1$} \\
\hline Cardio-respiratory arrest & $916(59.3)$ \\
\hline Acute respiratory failure & $132(8.5)$ \\
\hline Acute cardiovascular failure & $22(1.5)$ \\
\hline Acute neurological failure & $294(19.0)$ \\
\hline Voluntary intoxication & $68(4.4)$ \\
\hline Medical etiology without precision & $5(0.3)$ \\
\hline Severe trauma & $108(7.0)$ \\
\hline \multicolumn{2}{|l|}{ Rapid sequence induction, $\mathrm{N}(\%)$} \\
\hline \multicolumn{2}{|l|}{ Missing $N=5$} \\
\hline Yes & $684(44.4)$ \\
\hline No & $857(55.6)$ \\
\hline
\end{tabular}




$\begin{array}{|ll|}\text { Sedative drug, } \mathbf{N}(\%) & \\ \text { Missing } \mathbf{N}=4 & 597(87.3) \\ \text { Etomidate } & 48(7.0) \\ \text { Ketamine } & 4(0.6) \\ \text { Propofol } & 31(4.5) \\ \text { Nesdonal } & \\ \text { Myorelaxant drugs, } \mathbf{N}(\%) & \\ \text { Missing N = 11 } & 660(96.5) \\ \text { Succinylcholine } & 13(1.9) \\ \text { Rocuronium } & \end{array}$

IQR, interquartile range

Table 4: Factors associated with failure of the first intubation attempt, as identified by univariate analyses. 


\begin{tabular}{|c|c|c|c|c|c|}
\hline Variable & $\begin{array}{l}\text { Missing } \\
\mathrm{N}\end{array}$ & $\begin{array}{l}1 \text { attempt } \\
\begin{array}{l}\mathrm{N}=1060 \\
(\%)\end{array}\end{array}$ & $\begin{array}{l}>1 \\
\text { attempt } \\
\begin{array}{l}\mathrm{N}=486 \\
(\%)\end{array}\end{array}$ & OR [95\% Cl] & $\begin{array}{l}\mathrm{p}- \\
\text { value }\end{array}$ \\
\hline Centers & 0 & & & & 0.0001 \\
\hline 1 & & $295(63.9)$ & $167(36.1)$ & 1 & \\
\hline 2 & & $196(66.4)$ & $99(33.6)$ & $0.9[0.7-1.2]$ & \\
\hline 3 & & $125(68.7)$ & $57(31.3)$ & $0.8[0.8-1.2]$ & \\
\hline 4 & & $42(72.4)$ & $16(27.6)$ & $0.7[0.4-1.2]$ & \\
\hline 5 & & $114(77.4)$ & $33(22.4)$ & $0.5[0.3-0.8]$ & \\
\hline 6 & & $176(82.2)$ & $38(17.8)$ & $0.4[0.3-0.6]$ & \\
\hline 7 & & $6(67)$ & $3(33)$ & $0.9[0.2-3.6]$ & \\
\hline 8 & & $20(57)$ & $15(43)$ & $1.3[0.7-2.7]$ & \\
\hline 9 & & $33(66)$ & $17(34)$ & $0.9[0.5-1.7]$ & \\
\hline 10 & & $53(56.4)$ & $41(43.6)$ & $1.4[0.9-2.1]$ & \\
\hline Function & 3 & & & & 0.007 \\
\hline Senior MD, AN & & $646(61.1)$ & $261(53.8)$ & 1 & \\
\hline Junior MD, Resident, ANS & & $412(38.9)$ & $224(46.2)$ & $1.3(1.1-1.7)$ & \\
\hline Experience level & 29 & & & & 0.0001 \\
\hline Simulation, weak, moderate & & $326(31.3)$ & $233(48.8)$ & $2.1[1.7-2.6]$ & \\
\hline Good or very good & & $714(68.7)$ & $244(51.2)$ & 1 & \\
\hline $\begin{array}{l}\text { Number of prior intubations } \leq \\
50\end{array}$ & 36 & $433(41.6)$ & $257(54.7)$ & $1.7[1.4-2.1]$ & 0.0001 \\
\hline Operator position during & 36 & & & & 0.3 \\
\hline Unriaht & & $292(28.2)$ & $122(25.7)$ & 1 & \\
\hline 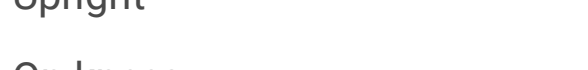 & & $470(45.4)$ & $222(46.7)$ & $1.1[0.9-1.4]$ & \\
\hline Surnees & & $146(14.1)$ & $82(17.3)$ & $1.3[0.9-1.9]$ & \\
\hline 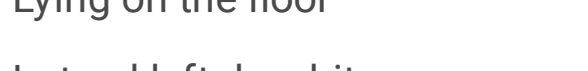 & & $90(8.7)$ & $39(8.2)$ & $1.0[0.7-1.6]$ & \\
\hline Other & & $37(3.6)$ & $10(2.1)$ & $0.6[0.3-1.3]$ & \\
\hline Gender, M & 14 & $654(62.3)$ & $330(68.5)$ & $1.3[1.0-1.6]$ & 0.02 \\
\hline Age, years, mean (SD) & 12 & $61.9(18.8)$ & 59.8 & 0.99 [0.99-1.0] & 0.04 \\
\hline
\end{tabular}


(17.8)

\begin{tabular}{|llllll|} 
Weight, kg, mean (SD) & 55 & $75.1(17.4)$ & $\begin{array}{l}79.8 \\
(20.2)\end{array}$ & $\begin{array}{l}1.01[1.00- \\
1.08]\end{array}$ & 0.0001 \\
\hline $\begin{array}{l}\text { Body mass index, } \mathrm{kg} \cdot \mathrm{m}^{-2} \text {, mean } \\
\text { (DS) }\end{array}$ & 175 & $25.7(5.5)$ & $27.2(6.5)$ & $\begin{array}{l}1.04[1.02- \\
1.06]\end{array}$ & 0.0001 \\
\hline Macroglossia & 18 & $130(12.4)$ & $131(27.2)$ & $2.6[2.0-3.5]$ & 0.0001 \\
\hline Facial malformation & 16 & $4(0.4)$ & $8(1.7)$ & $4.4[1.3-14.7$ & 0.02 \\
\hline Goiter & 18 & $9(0.9)$ & $10(2.1)$ & $2.4[1.0-6.1]$ & 0.05 \\
\hline ENT tumor & 17 & $6(0.6)$ & $12(2.5)$ & $4.4[1.7-11.9]$ & 0.003 \\
\hline Inter-incisor space & 73 & & & & 0.0001 \\
\hline$<2$ fingerbreadths & & $148(14.6)$ & $137(29.7)$ & $2.5[1.9-3.2]$ & \\
\hline
\end{tabular}




\begin{tabular}{|c|c|c|c|c|c|}
\hline Limited head extension & 40 & $\begin{array}{l}174 \\
(16.8)\end{array}$ & $\begin{array}{l}137 \\
(29.1)\end{array}$ & $\begin{array}{l}2.0[1.6- \\
2.6]\end{array}$ & 0.0001 \\
\hline $\begin{array}{l}\text { Immobilization of the head during } \\
\text { intubation }\end{array}$ & 40 & $\begin{array}{l}122 \\
(11.8)\end{array}$ & $75(16.0)$ & $\begin{array}{l}1.4[1.0- \\
1.9]\end{array}$ & 0.03 \\
\hline Mandibular subluxation & 72 & $\begin{array}{l}107 \\
(10.6)\end{array}$ & $86(18.6)$ & $\begin{array}{l}1.9[1.4- \\
2.6]\end{array}$ & 0.0001 \\
\hline Thyromental length & 98 & & & & 0.0001 \\
\hline$<3$ fingerbreadths & & $\begin{array}{l}189 \\
(18.9)\end{array}$ & $\begin{array}{l}131 \\
(29.2)\end{array}$ & $\begin{array}{l}1.8[1.4- \\
2.3]\end{array}$ & \\
\hline Neck size & 43 & & & & 0.0001 \\
\hline Large & & $\begin{array}{l}165 \\
(16.0)\end{array}$ & $\begin{array}{l}141 \\
(29.9)\end{array}$ & $\begin{array}{l}2.2[1.7- \\
2.9]\end{array}$ & \\
\hline Foreign body in upper airway & 18 & $52(5.0)$ & $28(5.8)$ & $\begin{array}{l}1.2[0.7- \\
1.9]\end{array}$ & 0.5 \\
\hline Missing anterior teeth & 19 & $\begin{array}{l}238 \\
(22.8)\end{array}$ & $\begin{array}{l}108 \\
(22.5)\end{array}$ & $\begin{array}{l}0.9[0.7- \\
1.3]\end{array}$ & 0.9 \\
\hline Upper airway bleeding/fluid & 18 & $90(8.6)$ & $66(13.7)$ & $\begin{array}{l}1.7[1.2- \\
1.3]^{[}\end{array}$ & 0.002 \\
\hline Facial trauma & 16 & $63(6.0)$ & $44(9.1)$ & $\begin{array}{l}1.6[1.0- \\
2.3]\end{array}$ & 0.03 \\
\hline Vomiting & 16 & $\begin{array}{l}181 \\
(17.3)\end{array}$ & $\begin{array}{l}119 \\
(24.7)\end{array}$ & $\begin{array}{l}1.6[1.2- \\
2.0]\end{array}$ & 0.001 \\
\hline Cardiorespiratory arrest & 1 & $\begin{array}{l}605 \\
(57.1)\end{array}$ & $\begin{array}{l}311 \\
(64.1)\end{array}$ & $\begin{array}{l}1.3[1.1- \\
1.7]\end{array}$ & 0.009 \\
\hline Trauma & 522 & $97(13.6)$ & $66(21.1)$ & $\begin{array}{l}1.7[1.2- \\
2.3]\end{array}$ & 0.003 \\
\hline Patient on the floor & 23 & $\begin{array}{l}649 \\
(62.3)\end{array}$ & $\begin{array}{l}316 \\
(65.6)\end{array}$ & $\begin{array}{l}1.2[0.9- \\
1.4]\end{array}$ & 0.2 \\
\hline Place where intubation was done & 50 & & & & 0.01 \\
\hline Outside & & 136 & $93(20.0)$ & $\begin{array}{l}1.6[1.2- \\
23]\end{array}$ & \\
\hline $\begin{array}{l}\text { At home } \\
\text { Others }\end{array}$ & & $\begin{array}{l}517 \\
(50.2)\end{array}$ & $\begin{array}{l}218 \\
(46.8)\end{array}$ & $\begin{array}{l}1.0[0.8- \\
1.3]^{[0.8}\end{array}$ & \\
\hline Ambulance & & $\begin{array}{l}105 \\
(10.2)\end{array}$ & 114 & $\begin{array}{l}0.9[0.6- \\
1.4]^{[}\end{array}$ & \\
\hline & & $\begin{array}{l}272 \\
(26.4)\end{array}$ & & 1 & \\
\hline Restricted space & 33 & $\begin{array}{l}374 \\
(36.1)\end{array}$ & $\begin{array}{l}188 \\
(39.4)\end{array}$ & $\begin{array}{l}1.1[0.9- \\
1.4]\end{array}$ & 0.2 \\
\hline
\end{tabular}


OR: odds ratios; $95 \% \mathrm{Cl}$ : $95 \%$ confidence intervals.

Table 5: Multivariate analysis

\begin{tabular}{|lll|}
\hline Variable & Odds Ratio & $95 \%$ Confidence Interval \\
\hline Center & & \\
2 & 1 & \\
3 & 0.9 & $0.6-1.2$ \\
4 & 0.9 & $0.6-1.5$ \\
5 & 0.3 & $0.2-0.8$ \\
6 & 0.6 & $0.3-0.9$ \\
7 & 0.3 & $0.2-0.5$ \\
8 & 0.7 & $0.1-3.9$ \\
9 & 1.1 & $0.5-2.6$ \\
\hline 10 & 0.7 & $0.3-1.5$ \\
\hline Number of prior intubations $\leq 50$ & 1.2 & $0.7-2.1$ \\
\hline Sex, M & 1.8 & $1.4-2.4$ \\
\hline Age, years & 1.3 & $0.99-1.71$ \\
\hline Macroglossia & 0.99 & $0.98-1.0$ \\
\hline ENT tumor & 2.3 & $1.6-3.2$ \\
\hline Inter-incisor space $(<2$ fingerbreadths $)$ & 2.3 & $1.4-13.4$ \\
\hline Thyromental length $(<3$ fingerbreadths $)$ & 1.2 & $0.9-1.7$ \\
\hline Limitation of head extension & 1.6 & $1.1-2.1$ \\
\hline Vomiting & 1.7 & $1.3-2.3$ \\
\hline Cardio-respiratory arrest & 1.8 & $1.3-2.6$ \\
\hline Patient on the floor & 1.3 & $0.9-1.8$ \\
\hline
\end{tabular}

Multivariate analysis adjusted for gender, age, centers, and variables with a $p$-value $\leq 0.2$ in univariate analyses, conducted using a backward step-by-step logistic regression model. 


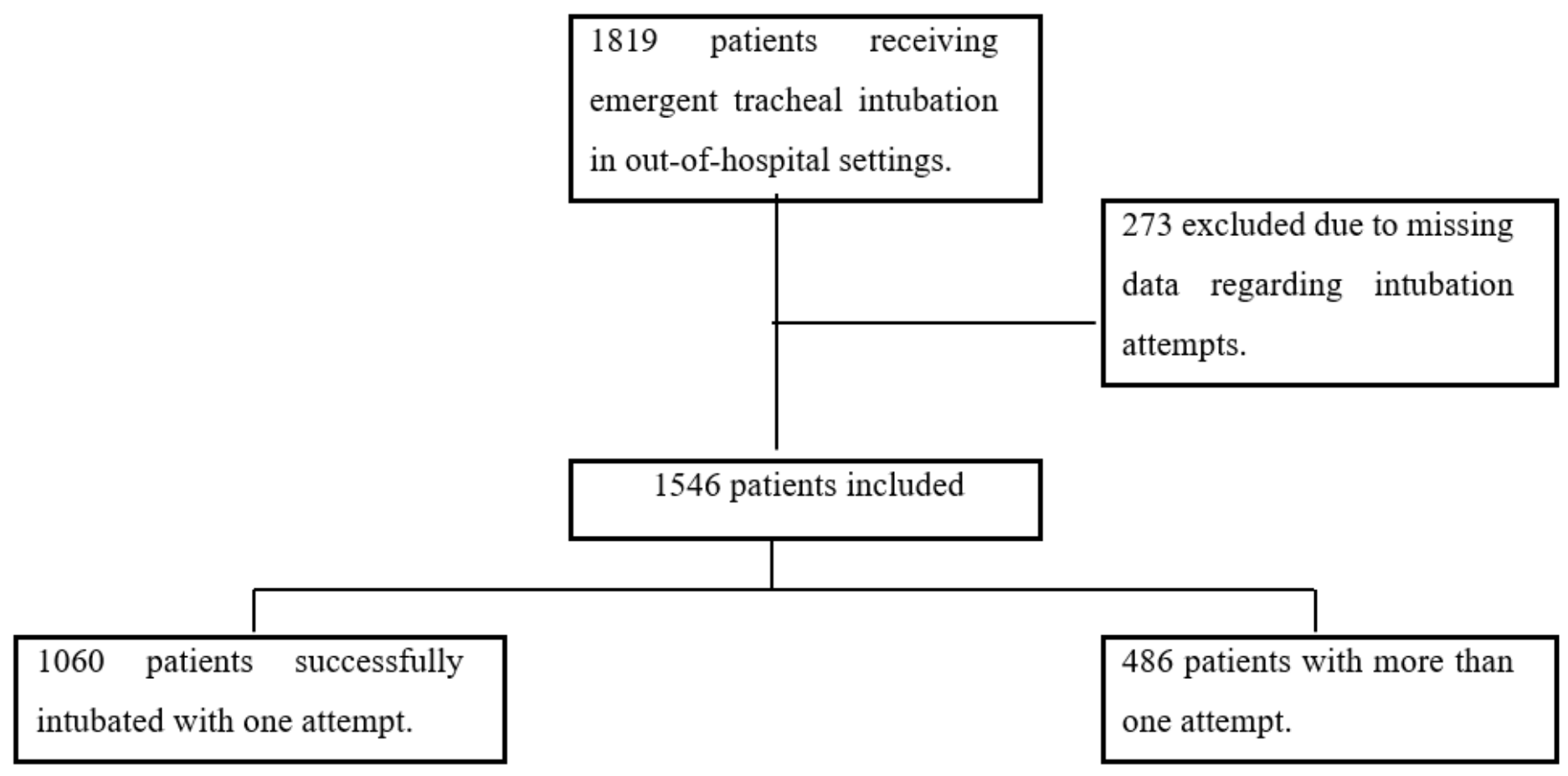

Figure 1

Flow chart

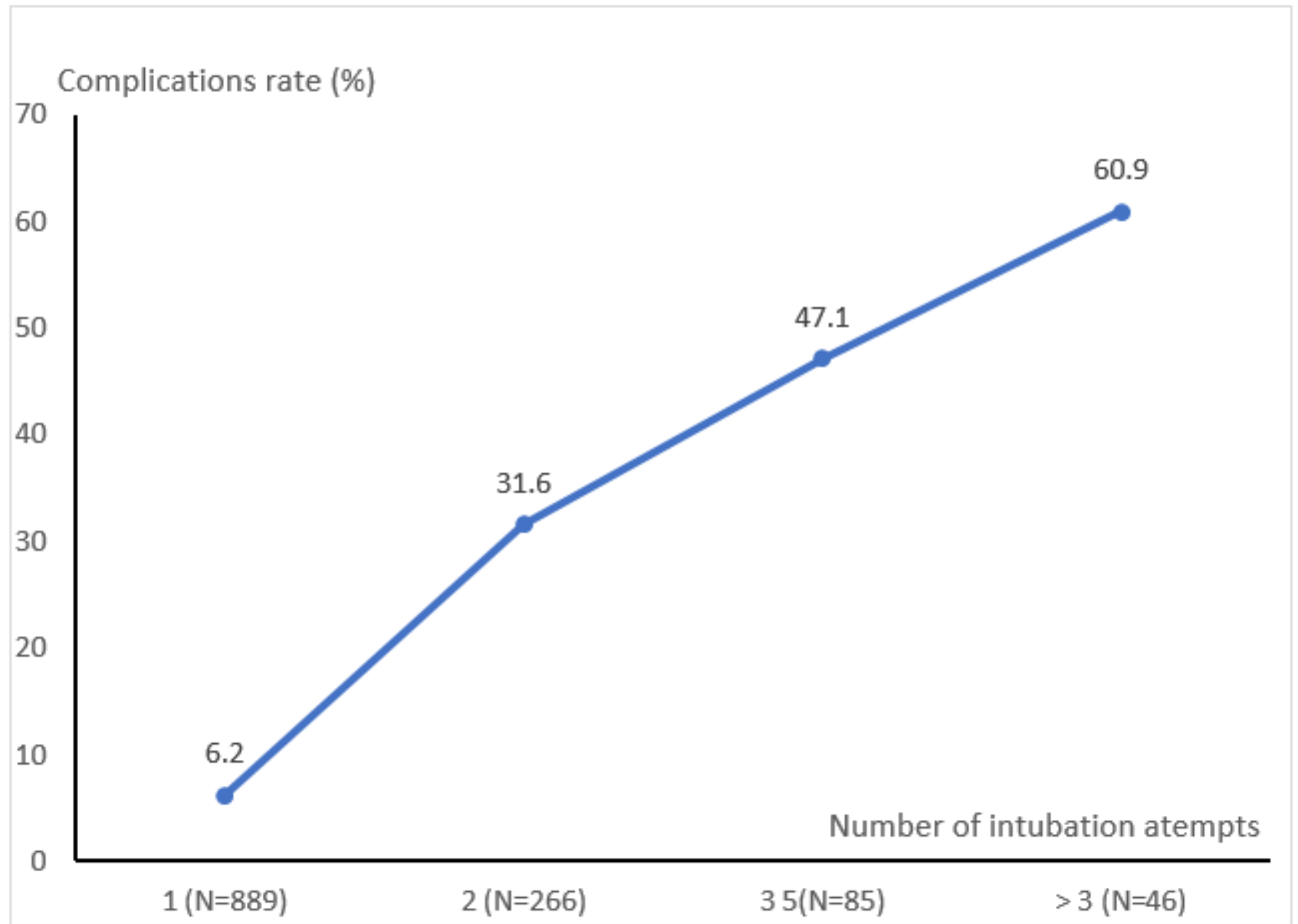


Figure 2

Complication rates according to number of intubation attempts.

\section{Supplementary Files}

This is a list of supplementary files associated with this preprint. Click to download.

- Additionalfile1.docx

- Additionalfile2.docx 